\title{
Pengaruh Kompetisi dan Kooperasi Melalui Koopetisi Terhadap Kinerja Perusahaan
}

(Studi Kasus Pada Umkm Retail Komputer Di Scc, Plaza Simpang Lima Semarang)

Njoo, Conny Elysia Lazaroni, Sentot Suciarto Athanasius

email: connyelysia@yahoo.com

Magister Manajemen Unika Soegijapranata

\begin{abstract}
This research examines the effect of competition and cooperation toward performance through coopetition of computer retail SMEs. This research used path analysis toward 31 SMEs computer retail by purposive sampling. Data collected by questionnaires. The research result showed that competition did not influence toward cooperation and performane, coopetition showed positive effect toward coopetition and business performance. Competition and cooperation through coopetition did not affect business performance.
\end{abstract}

Key words: coopetition, competition, cooperation, firm performance

\section{PENDAHULUAN}

Konsep persaingan pada umumnya adalah win-lose, dimana suatu perusahaan berusaha mengalahkan pesaing untuk menjadi pemenang pasar (Prasastyo, 2010). Kompetisi akan dimenangkan oleh perusahaan yang memiliki sumber daya lebih unggul, sebaliknya perusahaan dengan sumber daya yang lebih terbatas cenderung kalah. Bagi perusahaan dengan sumber daya terbatas, strategi kompetisi menjadi sulit dimenangkan. Salah satu strategi bisnis lainnya yang dapat dapat diterapkan yaitu kemitraan atau berkooperasi dengan pihak lain. Kooperasi dalam bisnis mengkolaborasikan sumber daya untuk mencapai tujuan bersama. Dengan demikian, kooperasi memberi manfaat lebih besar bagi perusahaan dan meningkatkan keunggulan perusahaan melalui kolaborasi sumber daya. Berbeda dengan kompetisi yang cenderung memisahkan business pie, kooperasi dalam sebuah bisnis cenderung memperluas business pie(Lendel, 2007). 
Kerjasama atau kooperasi dapat dilakukan bersama pemasok, distributor, dan pihak lain di sekitar perusahaan. Namun Brandenburger dan Nalebuff (1996) mengemukakan konsep baru kerjasama yaitu kooperasi dengan kompetitor atau disebut koopetisi. Dalam teori dinamik kompetitif, perusahaan dapat berkinerja lebih baik apabila menggunakan strategi kompetisi agresif. Sedangkan pada teori jaringan, perusahaan dapat menikmati manfaat dari relasi. Namun teori koopetisi menyatakan bahwa perusahaan yang sukses adalah perusahaan yang menerapkan manfaat kompetisi agresif dan kooperasi (Roy dan Sanou, 2014).

Di tengah era kompetisi global dengan saling ketergantungan dan tingkat perubahan yang tinggi, strategi koopetisi dapat digunakan untuk berbagi biaya dan resiko, memimpin inovasi, dan secara kolektif mengembangkan sumber daya dan kapabilitas bersama kompetitor (Aladag, 2013).Contoh keberhasilan perusahaan yang menerapkan koopetisi adalah ATM bersama (Siregar, 2006), MedUnite (IBM Global Services), Amazon Marketplace, Amazon Services dan Amazon web Services, Amazon Kindle (Ritala, 2014), Pic-Saint Loup wine cluster (Granata, 2013) dan lain-lain.

Eikobrokk dan Olsen (2005) menyatakan bahwa UMKM memiliki pengetahuan akan inovasi yang baik namun belum dapat mencapai keunggulan kompetitif berkelanjutan. UMKM juga memiliki sumber daya yang langka, memiliki konsumen yang sedikit namun loyal. Berdasarkan keterbatasan tersebut, UMKM perlu menerapkan kerjasama antar UMKM untuk mencapai pertumbuhan jangka panjang.

Sebagian besar UMKM di Indonesia merupakan industri perdagangan ritel. Industri perdagangan ritel merupakan sub-sektor penyumbang PDB terbesar kedua di Indonesia yaitu sebesar 11,58\% dari total PDB Indonesia tahun 2013 (BPS, 2014). Industri perdagangan ritel memiliki ragam produk yang luas dan beragam, sehingga industri ini menyumbang sebagian besar pendapatan negara dan mempekerjakan jumlah tenaga kerja yang besar pula. Pertumbuhan pendapatan ritel tahun 2012 sebesar 13\%-15\% dari tahun sebelumnya. 
Besarnya jumlah pemain dalam sektor perdagangan dapat meningkatkan intensitas kompetisi. Salah satunya adalah kompetisi harga, dimana masingmasing kompetitor berusaha memberi harga terbaik untuk menarik konsumen membeli produknya. Persaingan harga antar bisnis menjadi hal yang sangat wajar dalam sektor perdagangan. Namun (Khasali, 2010) menyatakan bahwa sektor perdagangan dengan produk yang sama pun dapat menciptakan multiple-winners.

Salah satu lokasi dengan beberapa penjual produk yang sama adalah Semarang Computer Center di Plaza Simpang Lima lantai 5 Semarang. Lokasi ini didirikan sejak 1 April 2004 yang terdiri dari 20 toko. Seiring dengan peningkatan permintaan, SCC ini berkembang hingga saat ini terdiri dari \pm 90 plot kios dengan fasilitas free hotspot, training center, cafe, dan exhibition hall. Peningkatan jumlah toko yang bergabung dalam SCC menandakan peningkatan kompetisi industri khususnya dalam area SCC.Berkumpulnya beberapa toko sejenis dalam satu area menjadikan SCC sebagai pusat komputer, sehingga lebih memudahkan konsumen memenuhi segala kebutuhan komputer.

Roy dan Sanou (2014) dalam penelitiannya membagi 190 perusahaan telekomunikasi dalam 3 kategori perusahaan dengan strategi kooperasi, kompetisi, dan koopetisi kemudian membandingkan pengaruh masing-masing strategi terhadap kinerja. Hasil penelitian menunjukkan perusahaan yang menerapkan strategi koopetisi memiliki kinerja lebih baik dibandingkan dengan perusahaan yang menerapkan strategi kooperasi murni dan kompetisi murni. Penelitian Roy dan Sanou (2014) juga mengungkapkan setelah strategi koopetisi, strategi kompetisi berpengaruh terhadap kinerja perusahaan dibandingkan dengan strategi kooperasi.

Penelitian Garcia dan Velasco (2002) pada industri bioteknologi di Eropa, mengemukakan bahwa kooperasi dengan kompetitor berpengaruh signifikan terhadap kompetensi inovasi produk dan teknologi. Morris, Kocak, dan Ozer (2007) mengemukakan pengaruh positif dari tiga dimensi koopetisi (mutualisme, kepercayaan, dan komitmen) terhadap kinerja perusahaan. Eikobrokk dan Olsen 
(2005) mengemukakan adanya pengaruh koopetisi terhadap kesuksesan UMKM $e$-business. Terdapat korelasi positif antara koopetisi dan kinerja e-business dalam hal efisiensi, komplementor, lock-in, dan novelty.

Belum terdapat pembahasan mengenai peran mediasi dari koopetisi dalam mempengaruhi kompetisi dan kooperasi terhadap kinerja perusahaan. Berdasarkan hal tersebut, maka peneliti melakukan penelitian yang berjudul "Pengaruh Kompetisidan Kooperasi melalui Koopetisiterhadap Kinerja Perusahaan(Studi kasus pada UMKM ritel komputer di Semarang Computer Center Plaza Simpang Lima Semarang)”

\section{Rumusan Masalah}

Berkumpulnya toko dalam satu area diharapkan dapat menarik dan mempermudah konsumen melakukan keputusan pembelian karena adanya beragam pilihan dan kemudahan informasi. Berdasarkan hal tersebut, peneliti merumuskan masalah:

a. Bagaimana pengaruh kompetisi terhadap kinerja perusahaan?

b. Bagaimana pengaruh kooperasi terhadap kinerja perusahaan?

c. Bagaimana pengaruh kompetisi terhadap koopetisi?

d. Bagaimana pengaruh kooperasi terhadap koopetisi?

e. Bagaimana pengaruh koopetisi terhadap kinerja?

f. Bagaimana pengaruh kompetisi dan kooperasimelalui Koopetisi terhadap kinerja perusahaan?

Tujuan penelitian ini adalah untuk mengetahuipengaruh kooperasi dan kompetisi secara parsial terhadap kinerja perusahaan, pengaruh kompetisi dan kooperasi terhadap koopetisi, pengaruh koopetisi terhadap kinerja perusahaan,dan pengaruh kompetisi dan kooperasimelalui koopetisiterhadap kinerja perusahaan pada UMKM ritel komputer yang tergabung dalam SCC Plaza Simpang Lima Semarang. 


\section{TINJAUAN PUSTAKA}

Keunggulan perusahaan dikategorikan oleh Porter (1980) dalam 2 bagian: keunggulan biaya dan diferensiasi. Perusahaan yang memiliki keunggulan biaya, memiliki struktur biaya yang lebih rendah daripada pesaingnya. Keunggulan biaya ini mengarahkan perusahaan pada kompetisi yang agresif (Hooley, dkk, 2008).

\section{Kompetisi}

Kompetisi muncul karena satu atau lebih pesaing merasa terhimpit atau melihat peluang untuk mengubah posisi mereka menjadi lebih baik. Kompetisi terjadi karena industri berubah semakin dinamis, perubahan yang terus menerus, adanya intensitas persaingan antar perusahaan (Johansson, 2012), dan adanya konflik kepentingan antar perusahaan (Eikobrokk dan Olsen, 2005).

Strategi kompetisi yang dilakukan perusahaan adalah aksi dan reaksi, yaitu dengan melakukan tindakan kompetitif lebih bervariasi dan lebih cepat daripada kompetitor, merespon lebih cepat daripada kompetitor, meminimalisir kerjasama formal maupun informal (Roy dan Sanou, 2014). Kompetisi menutup kemungkinan kerjasama dan berusaha melindungi sumber daya dan kapabilitasnya dari pesaing (Garcia, 2002).

Penciptaan nilai dalam kompetisi adalah saat kompetitor memenangkan suatu nilai, maka nilai tersebut menjadi kekalahan bagi kompetitor lainnya. Kompetisi cenderung menurunkan tingkat pengembalian sehingga mengarahkan suatu industri menjadi persaingan sempurna dan pasar bebas. (Porter, 1998).Sebagian besar definisi kompetisi yang berkembang adalah kompetisi dari segi struktur, sedangkan Bengtsson dan Kock (2000) menjelaskan definisi kompetisi yang lain dilihat dari segi hubungan yang terjalin.

Kompetisi adalah proses interaktif dimana organisasi dalam perusahaan memberi andil dalam strategi yang dilakukan perusahaan dan mempengaruhi interaksi antar kompetitor. Menurut Bengtsson dan Kock (2000), kompetisi merupakan interaksi yang menguntungkan, dibandingkan dengan kooperasi yang 
cenderung menghilangkan manfaat dari kompetisi.Persaingan merupakan proses dimana masing-masing perusahaan berupaya menarik konsumen membeli produknya dengan cara menekan harga, melakukan persaingan non harga, dan meningkatkan efisiensi. Kompetisi berdampak efisiensi harga bagi konsumen sekaligus meningkatkan inovasi.Pada beberapa teori, kooperasi dalam level yang lebih besar mengarah kepada bentuk monopoli (Walley, 2007).

\section{Kooperasi}

Kooperasi adalah bekerjasama dengan pihak lain untuk manfaat mutualisme (Waxse, 2012). Kooperasi menggambarkan situasi dimana hubungan antar rekan kerja didominasi dengan lebih banyak kerjasama daripada kompetisi dengan menggabungkan sumber daya, kemampuan dan kapabilitas (Garcia,2002). Kooperasi sering diartikan kebalikan dari kompetisi, dimana kooperasi cenderung menjaga kestabilan harga dan menurunkan intensitas inovasi (Walley, 2007).

Kooperasi menggabungkan permintaan dan penawaran untuk meningkatkan keuntungan lebih besar daripada mengandalkan sumber daya perusahaan secara individual. Dalam hubungan kooperasi, perusahaan yang tergabung di dalamnya mengembangkan sumber daya dan kapabilitas untuk mencapai tujuan bersama (Reynolds, 2013).

Bagi perusahaan dengan sumber daya terbatas, kooperasi juga dapat menjadi alternatif strategi dibandingkan strategi kompetisi yang membutuhkan sumber daya yang besar dan kuat.Kerjasama dapat membantu mempertahankan posisi suatu bisnis di pasar, mengembangkan pengetahuan dan kinerja inovasi (Johansson, 2012).Pada dasarnya, kerjasama atau kooperasi memiliki tujuan winwin solution dimana kerjasama harus menguntungkan kedua belah pihak. Manfaat kerjasama (Budiwakti, 2006) adalah:meningkatkan produktivitas, efektivitas, dan efisiensi; menciptakan lingkungan kompetisi yang sehat; menjamin keberlangsungan usaha; dan mengurangi resiko bisnis. 


\section{Koopetisi}

Teori koopetisi didahului oleh konsep kompetisi dan kooperasi yang terpisah bahkan bertolak belakang. Pada sudut pandang kompetisi, perusahaan menciptakan hambatan dan membatasi kerjasama. Sedangkan sudut pandang kooperasi membuka diri bagi kerjasama mutualisme demi tercapai tujuan bersama (Garcia, 2002). Kompetisi cenderung memisahkan business pie, sedangkan kooperasi cenderung menggabungkan business pie.Namun terkadang perusahaan melakukan kompetisi dan kerjasama dalam berbagai kesempatan.

Saat perusahaan menerapkan strategi kompetisi dan kooperasi secara simultan, hal ini lah yang disebut koopetisi (Morris, 2007). Kombinasi manfaat kedua konsep tersebut kemudian dikembangkan oleh Nalebuff dan Brandenburger (1996)sebagai koopetisi.Koopetisi adalah "coopetitive relationship of firms to create value, and compete to get the biggest share of the value created”. Definisi lain koopetisi dikemukakan oleh Luo (2004) "In a general way coopetition could be defined as a phenomenon involving the simultaneous existence of both competition and cooperation in a single relationship”.

Aladag (2013) mendefinisikan koopetisi sebagai:“Coopetition is a strategic relationship, where firms from the same industry compete and cooperate simultaneously within a dynamic structure, in order to benefit from the synergies and efficiencies created through the common deployment of resource and capabilities in various areas and stages of their businesses”.Hubungan koopetisi dapat terjadi pada dua perusahaan yang intens bekerjasama pada departemen pengembangan produk namun juga bersaing ketat pada departemen pemasaran.

Brandenburger dan Nalebuff mengemukakan pandangan bahwa suatu persaingan dalam industri dapat lebih bermanfaat apabila berkooperasi daripada bersaing sendiri yang bersifat destruktif. Bisnis dapat sukses apabila bisnis lain juga sukses (mutual success), sehingga koopetisi adalah persaingan sekaligus kerjasama secara simultan (Evans, 2013). 
Brandenburger dan Nalebuff mendasarkan koopetisi pada business game dengan beberapa pemain (perusahaan) yang bermain dalam berbagai peran dan saling bergantung satu dengan yang lain. business game berbeda dengan perang dimana akan ada pemenang dan yang kalah. Dalam business game, pemain dapat mendapat keuntungan yang lebih banyak selama interaksi antar pemain menghasilkan pertambahan nilai secara keseluruhan. Dengan demikian, kesuksesan suatu perusahaan bukan berarti kekalahan dari lain perusahaan melainkan multiple winner (Kossyva, 2014).

\section{Kinerja Perusahaan}

Keberadaan UMKM berdampak besar bagi kemajuan ekonomi Indonesia, menjadikan kinerja UMKM sebagai isu penting yang harus dicermati. Kinerja UMKM dapat diukur berdasarkan finansial melalui total penjualan kotor dan laba kotor dan non-finansial melalui produktivitas perusahaan (Hoetoro, 2014). Kinerja finansial juga dapat diukur berdasarkan nilai sekarang suatu perusahaan, pengembangan produk baru termasuk input dan ouput $\mathrm{R} \& \mathrm{D}$, persepsi konsumen dan hubungan konsumen, dan posisi kompetitif pada pasar (Li, 2015).

Kinerja perusahaan juga dapat diukur melalui kinerja inovasi. Menurut Lillo dan Lajara (2002), Ha (2002), dan Garg (2003), pengukuran kinerja lebih efektif menggunakan data primer dan sekunder. UMKM cenderung sulit untuk menyediakan data sekunder yang akurat dan terpercaya. Data keuangan perusahaan mikro, kecil dan menengah juga cenderung sulit diinterpretasikan sebagai indikator. Data objektif menjadi kurang efektif sehingga perlu ditambah dengan ukuran kinerja subjektif melalui data primer. Dengan demikian, kinerja perusahaan dapat diukur melalui total penjualan, laba bersih, jumlah karyawan, dan produktivitas karyawan (Hoetoro, 2014).

\section{Penelitian Terdahulu}

Eikobrokk dan Olsen melakukan penelitian mengenai koopetisi dan kesuksesan e-business pada UMKM di Eropa. Hasil penelitian tersebut menyatakan koopetisi berdampak bagi kesuksesan e-business. Kossyva, Sarri, dan 
Nikolaos melakukan tinjauan literatur yang membahas koopetisi sebagai strategi bisnis untuk UMKM dalam menghadapi krisis. Kesimpulan tinjauan literatur tersebut menyatakan koopetisi bermanfaat dan dapat membantu UMKM menghadapi tantangan krisis ekonomi secara bersama. Le Roy dan Sanou melakukan penelitian pada perusahaan sektor telepon genggam mengenai strategi kompetisi, kooperasi, koeksistensi dan koopetisi dalam mempengaruhi kinerja. Hasil penelitian menyatakan koopetisi memiliki pengaruh paling besar dalam mempengaruhi kinerja.

Penelitian koopetisi terhadap kinerja juga pernah dilakukan oleh Garcia dan Velasco dalam industri bioteknologi di Eropa. Hasilnya bekerjasama dengan kompetitor adalah strategi yang paling relevan. Morris, Kocak, dan Ozer melakukan penelitian mengenai hubungan koopetisi terhadap kinerja pada perusahaan kecil di Turki. Hasilnya terdapat pengaruh positif antara dimensi koopetisi terhadap kinerja perusahaan. Penelitian kualitatif dilakukan oleh Granata mengenai strategi koopetisi pada industri anggur minum di Perancis yaitu Pic Saint-Loup. Hasil penelitian ini adalah koopetisi pada Pic Saint-Loup berhasil membantu produsen anggur kecil untuk bertahan di tengah kompetisi pasar anggur minum yang sebelumnya sulit karena didominasi oleh produsen besar.

\section{Hipotesis}

Hipotesis kesatuyaitu kompetisi berpengaruh terhadap kinerja perusahaan.

Hipotesis kedua yaitu kooperasi berpengaruh terhadap kinerja perusahaan.

Hipotesis ketiga yaitu kompetisi berpengaruh terhadap koopetisi

Hipotesis keempat yaitu kooperasi berpengaruh terhadap koopetisi.

Hipotesis kelima yaitu koopetisi berpengaruh terhadap kinerja.

Hipotesis keenam yaitu kompetisi dan kooperasi melalui koopetisi berpengaruh terhadap kinerja perusahaan

\section{Kerangka Pikir Penelitian}

Persaingan di sektor perdagangan menyebabkan kompetisi yang saling menjatuhkan. Namun konsep koopetisi mampu menjembatani permasalahan 
kompetisi dan kelemahan kooperasi dengan mengkombinasikan unsur kompetisi dan kooperasi. Dimana dua perusahaan atau lebih yang saling bersaing melakukan kerja sama untuk meningkatkan kinerja perusahaan itu sendiri dan perusahaanperusahaan lain yang turut bekerja sama.

Menurut Roy dan Sanou (2014), kinerja perusahaan bergantung pada strategi yang digunakan perusahaan terkait hubungan dengan kompetitornya, seperti strategi kompetisi agresif, kooperasi, maupun koopetisi. Peneliti menduga bahwa melalui strategi koopetisi, strategi kompetisi dan kooperasi memiliki pengaruh lebih besar dibandingkan penerapan langsung strategi kompetisi atau kooperasi terhadap kinerja. Berdasarkan hal tersebut, penelitian ini menguji model penelitian yang digambarkan sebagai berikut:

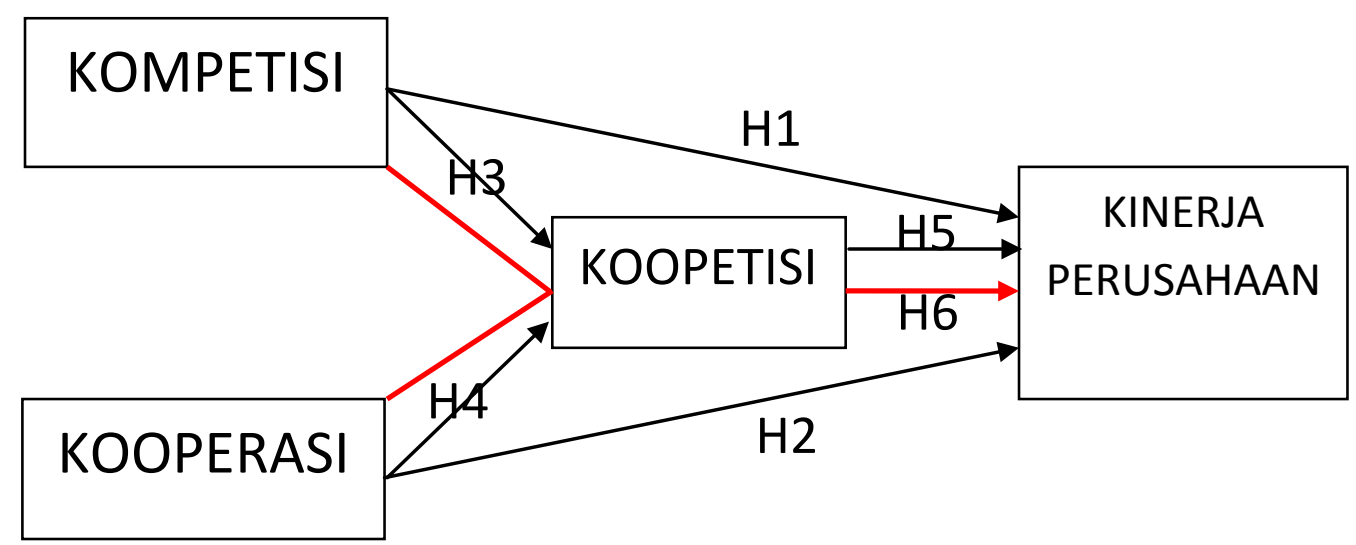

Gambar 1. Kerangka pikir penelitian

Berdasarkan kerangka pikir tersebut, penelitian ini menjelaskan pengaruh kompetisi terhadap kinerja perusahaan secara langsung, kooperasi terhadap kinerja secara langsung, dan kompetisi dan kooperasimelalui koopetisi terhadap kinerja.Penelitian ini menduga kompetisi dan kooperasi dapat mempengaruhi kinerja perusahaan lebih besar melalui kombinasi keduanya yaitu koopetisi. 
JEMAP : Jurnal Ekonomi, Manajemen, Akuntansi dan Perpajakan

ISSN : 2622-612X (Media Online) | Vol. 2 | No. 1| April 2019

\section{Definisi Operasional}

Variabel kompetisi didefinisikan sebagai kondisi dimana dua atau lebih perusahaan menunjukkan keunggulan masing-masing untuk menarik konsumen, mengalahkan pesaing dan adanya hambatan bagi pendatang baru untuk masuk pasar.

Variabel kooperasi didefinisikan sebagai kerjasama antara dua atau lebih perusahaan untuk mencapai tujuan bersama.

Variabel koopetisi didefinisikan sebagai hubungan kooperasi dan kompetisi secara simultan antar dua atau lebih perusahaan sejenis untuk meraih business pie yang lebih besar.

Variabel kinerja perusahaan didefinisikan sebagai hasil dari aktivitas perusahaan. Kinerja perusahaan pada penelitian ini diukur dengan kinerja finansial dengan indikator penambahan omset penjualan, penambahan laba bersih, dan penambahan aset. Penambahan aset yaitu adanya peningkatan jumlah karyawan dan kenaikan jumlah ready stok.

Tabel1

Definisi Operasional

\begin{tabular}{|c|c|c|}
\hline Variabel & Indikator & Item kuesioner \\
\hline \multirow[t]{3}{*}{ Kompetisi } & $\begin{array}{l}\text { Hambatan masuk pasar, dimana toko } \\
\text { baru dapat dengan mudah berjualan } \\
\text { dalam SCC dan menjadi pesaing baru } \\
\text { bagi toko lain yang sudah ada. } \\
\text { Semakin kecil hambatan masuk } \\
\text { pasar, maka semakin tinggi } \\
\text { kompetisi. }\end{array}$ & $\begin{array}{l}\text { 1. Persyaratan mudah bagi toko } \\
\text { komputer baru untuk berjualan dalam } \\
\text { SCC. } \\
\text { 2. Toko yang telah dahulu ada di } \\
\text { SCC tidak mempersulit atau } \\
\text { menjatuhkan toko baru yang } \\
\text { berjualan di SCC }\end{array}$ \\
\hline & $\begin{array}{l}\text { Kekuatan tawar pelanggan, dimana } \\
\text { konsumen dengan mudah berpindah } \\
\text { ke toko lain apabila tidak cocok } \\
\text { dengan penawaran suatu toko. }\end{array}$ & $\begin{array}{l}\text { 1. Konsumen sering membandingkan } \\
\text { harga antar toko. } \\
\text { 2. Konsumen mudah berpindah ke } \\
\text { toko lain apabila tidak terjadi } \\
\text { kesepakatan harga di toko saya. }\end{array}$ \\
\hline & $\begin{array}{l}\text { Ancaman pesaing sejenis, dimana } \\
\text { toko pesaing menjual produk sejenis } \\
\text { dengan harga bersaing. }\end{array}$ & $\begin{array}{l}\text { 1. Banyak toko menjual barang } \\
\text { sejenis } \\
\text { 2.Toko lain yang sejenis sering } \\
\text { memberi promosi yang menarik } \\
\text { konsumen saya. } \\
\text { 3. Toko lain yang sejenis } \\
\text { menawarkan harga yang lebih murah } \\
\text { daripada toko saya. }\end{array}$ \\
\hline Kooperasi & mencapai & 1. Saya ingin mengurangi intensitas \\
\hline
\end{tabular}




\begin{tabular}{|c|c|c|}
\hline Variabel & Indikator & Item kuesioner \\
\hline & $\begin{array}{l}\text { dimana toko bekerjasama dengan } \\
\text { pihak lain untuk mencapai } \\
\text { kesejahteraan bersama. }\end{array}$ & $\begin{array}{l}\text { persaingan dengan bekerjasama } \\
\text { dengan pihak lain untuk mencapai } \\
\text { kesejahteraan bersama. } \\
\text { 2.Saya melakukan kerjasama } \\
\text { informal } \\
\text { 3. Saya melakukan kerjasama formal }\end{array}$ \\
\hline & $\begin{array}{l}\text { Kolaborasi sumber daya dan } \\
\text { kapabilitas, dimana toko berbagi } \\
\text { sumber daya yang dimilikinya bagi } \\
\text { pihak lain yang bekerjasama. }\end{array}$ & $\begin{array}{l}\text { 1. Saya berbagi informasi dan sumber } \\
\text { daya dengan rekan saya. } \\
\text { 2. Saya membantu kesuksesan rekan } \\
\text { saya melalui sumber daya yang saya } \\
\text { miliki. } \\
\text { 3. Saya banyak mendapat bantuan } \\
\text { dari rekan kerjasama saya. } \\
\text { 4. melalui kolaborasi sumber daya } \\
\text { dan informasi dengan rekan } \\
\text { kerjasama, saya dapat meningkatkan } \\
\text { efisiensi dan keuntungan daripada } \\
\text { mengandalkan sumber daya saya } \\
\text { sendiri. }\end{array}$ \\
\hline & $\begin{array}{l}\text { Manfaat mutualisme, dimana toko } \\
\text { mendapatkan manfaat mutualisme } \\
\text { dengan toko lain, demikian pula } \\
\text { sebaliknya. }\end{array}$ & $\begin{array}{l}\text { 1. Saya dan rekan kerjasama sama- } \\
\text { sama mendapat keuntungan atas } \\
\text { hubungan kerjasama. } \\
\text { 2. Penting bagi saya untuk mencapai } \\
\text { tujuan bersama daripada meraih } \\
\text { keuntungan sepihak saja. } \\
\text { 3. Sumber daya dan informasi yang } \\
\text { kami dapat dari lain pihak bermanfaat } \\
\text { bagi kesuksesan usaha kami bersama. }\end{array}$ \\
\hline \multirow[t]{3}{*}{ Koopetisi } & $\begin{array}{l}\text { Mutualisme, dimana toko yang } \\
\text { berkoopetisi memberikan manfaat } \\
\text { timbal balik bagi toko yang } \\
\text { bekerjasama }\end{array}$ & $\begin{array}{l}\text { 1. Walaupun partner saya adalah } \\
\text { kompetitor, saya tidak ragu untuk } \\
\text { membangun hubungan apabila hal } \\
\text { tersebut dapat memajukan bisnis } \\
\text { saya. } \\
\text { 2. walaupun partner saya adalah } \\
\text { kompetitor, kami terbuka untuk } \\
\text { berbagi sumber daya dan informasi. } \\
\text { 3. untuk membangun hubungan } \\
\text { kerjasama, kedua perusahaaan harus } \\
\text { memiliki tujuan yang sama-sama } \\
\text { menguntungkan. }\end{array}$ \\
\hline & $\begin{array}{l}\text { Kepercayaan, dimana toko yang } \\
\text { berkoopetisi percaya bahwa toko } \\
\text { yang bekerjasama dengannya adalah } \\
\text { jujur, dapat dipercaya, dan tidak } \\
\text { memiliki niat terselubung untuk } \\
\text { mengambil keuntungan pribadi } \\
\text { secara sepihak }\end{array}$ & $\begin{array}{l}\text { 1. Saya percaya toko yang } \\
\text { bekerjasama dengan saya jujur pada } \\
\text { saya dan dapat dipercaya atau } \\
\text { diandalkan sekalipun toko tersebut } \\
\text { juga adalah pesaing saya. } \\
\text { 2. hubungan akan terganggu apabila } \\
\text { partner saya mencoba mengambil } \\
\text { keuntungan dari perusahaan saya. } \\
\text { 3. partner harus selalu jujur dalam } \\
\text { suatu hubungan }\end{array}$ \\
\hline & $\begin{array}{lrr}\text { Komitmen, } & \text { dimana } & \text { toko yang } \\
\text { berkoopetisi } & \text { memiliki } & \text { komitmen } \\
\text { menjaga } & \text { hubungan } & \text { koopetisi }\end{array}$ & $\begin{array}{l}\text { 1. Saya berkomitmen untuk menjaga } \\
\text { hubungan baik dengan toko lain yang } \\
\text { bekerjasama dengan saya. }\end{array}$ \\
\hline
\end{tabular}


JEMAP : Jurnal Ekonomi, Manajemen, Akuntansi dan Perpajakan ISSN : 2622-612X (Media Online) | Vol. 2 | No. 1| April 2019

\begin{tabular}{|c|c|c|}
\hline Variabel & Indikator & Item kuesioner \\
\hline & $\begin{array}{l}\text { berlangsung baik untuk jangka } \\
\text { panjang dengan toko lain. }\end{array}$ & $\begin{array}{l}\text { 2. kedua pihak harus memiliki niat } \\
\text { untuk membantu memajukan usaha } \\
\text { pihak lainnya. } \\
\text { 3. saya bersedia bertanggung jawab } \\
\text { dan berkomitmen untuk tujuan } \\
\text { bersama dari hubungan kerjasama ini. }\end{array}$ \\
\hline \multirow[t]{3}{*}{$\begin{array}{l}\text { Kinerja } \\
\text { perusahaan }\end{array}$} & 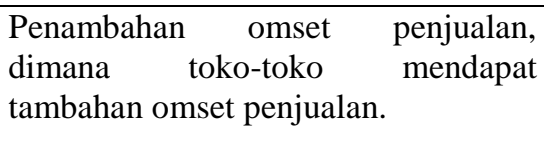 & $\begin{array}{l}\text { 1. Terjadi peningkatan jumlah unit } \\
\text { yang terjual. } \\
\text { 2. Ada peningkatan jumlah } \\
\text { pengunjung toko. }\end{array}$ \\
\hline & Penambahan laba bersih & $\begin{array}{l}\text { 1. Adanya peningkatan laba } \\
\text { 2. Saya dapat mengurangi biaya } \\
\text { operasional (contoh biaya promosi, } \\
\text { dll). }\end{array}$ \\
\hline & Pertambahan aset & $\begin{array}{l}\text { 1. Adanya pertambahan jumlah } \\
\text { karyawan } \\
\text { 2. Kenaikan jumlah stok barang ready } \\
\text { stock. }\end{array}$ \\
\hline
\end{tabular}

\section{METODE PENELITIAN}

\section{Obyek dan Lokasi Penelitian}

Obyek penelitian iniyaitu Semarang Computer Centre di Simpanglima Semarang,dipilih karena terdapat beberapa toko dengan produk sejenis dan melayani pasar yang sama dalam satu lokasi. SCC dikenal sebagai pusat komputer sehingga dapat memenuhi kebutuhan konsumen secara luas dan memudahkan konsumen mendapatkan informasi pasar sehinggameningkatkan daya tawar konsumen. Selain kompetisi, toko komputer di SCC juga melakukan kooperasi secara formal maupun non-formal. Kooperasi formal dengan bergabung dalam asosiasi pedagang komputer (APKOMINDO) dan kooperasi non-formal dengan bersepakat menentukan harga terendah, menjadi komplementor bagi toko lain yang membutuhkan produk tertentu, dan lain-lain. Lokasi penelitian ini adalah Plaza Simpang Lima lantai 5, Semarang.

\section{Populasi dan Sampel}

Populasi penelitian adalah seluruh tokoUMKM ritel komputer di SCC. Toko komputer yang tergabung dalam SCC melakukan kompetisi untuk dapat lebih menarik konsumen, di lain sisi melakukan kerjasama dengan toko-toko lain untuk 
meningkatkan sumber dayanya untuk kembali meningkatkan daya saing. Sebagian besar kompetisi terjadi dalam hal harga, sedangkan kooperasi terjadi dalam hal penyesuaian harga, komplementor, konsinyasi, dan lain-lain.

Sampel penelitian yang diambil dengan teknik purposive samplingadalah 31 toko UMKM yang berjualan di SCC.Di SCC, terdapat 90 plot kios yang tersedia bagi toko untuk berjualan di SCC baik di lantai 4 maupun 5. Dari 60 kios, beberapa diantaranya merupakan cabang dari kios lainnya.Hanya terdapat 40 toko komputer yang layak digunakan sebagai sampel. Namun dari 40 toko, hanya 31 toko yang berkenan untuk menjadi responden. Dengan demikian, sampel penelitian dipilih yang bersedia dan yang berada di lokasi penelitian.

\section{Pengumpulan Data}

Teknik Pengumpulan data yang digunakan dalam penelitian ini adalah kuesioner yang diisi oleh responden.Uji validitas dilakukan dengan melakukan korelasi bivariate antara masing-masing skor indikator dengan total skor konstruk. Apabila korelasi masing-masing indikator terhadap total skor konstruk menunjukkan hasil yang signifikan, maka dapat disimpulkan bahwa masingmasing indikator pertanyaan valid (Ghozali, 2011). Uji validitas kuesioner dapat dilakukan dengan metode convergent validity dan discriminant validity menggunakan program SmartPLS 3.0.Convergent validity dari measurement model dengan indikator reflektif dapat dilihat dari korelasi antara skor indikator dengan skor konstruknya (Ghozali, 2014). Berdasarkan hasil perhitungan tersebut, penelitian dapat dinyatakan memenuhi convergent validity karena semua outer loading memiliki nilai di atas 0.5. Dengan demikian, masing-masing konstruk memiliki variabel refleksif sebagai berikut:

Kompetisi memiliki variabel refleksif:

1. Hambatan masuk pasar digambarkan melalui item kuesioner 1

2. Kekuatan tawar pelanggan digambarkan melalui item kuesioner 4

3. Ancaman pesaing sejenis digambarkan melalui item kuesioner 6

Kooperasi memiliki variabel refleksif: 
1. Usaha mencapai tujuan bersama digambarkan melalui item kuesioner 2 dan 3 .

2. Kolaborasi sumber daya dan informasi digambarkan melalui item kuesioner 4, 5 , 6, dan 7 .

3. Manfaat mutualisme digambarkan melalui item kuesioner 8 dan 10.

Koopetisi memiliki variabel refleksif:

1. Mutualisme digambarkan melalui item kuesioner 2 dan 3

2. Kepercayaan digambarkan melalui item kuesioner 4

3. Komitmen digambarkan melalui item kuesioner 7, 8, dan 9

Kinerja memiliki variabel refleksif:

1. Penambahan omset penjualan digambarkan melalui item kuesioner 1 dan 2

2. Penambahan laba bersih digambarkan melalui item kuesioner 3 dan 4

3. Penambahan aset sejenis digambarkan melalui item kuesioner 5 dan 6

Uji Realibilitas dilakukan dengan mengukur korelasi antar jawaban pertanyaan. Suatu variabel dinyatakan reliabel jika memberikan nilai Composite reliability> 0,70. Kuesioner penelitian diuji reliabilitasnya dengan program SmartPLS dan menghasilkan output composite reliability sebagai berikut: Kinerja 0,820. Kompetisi 0,779. Kooperasi 0,852. Koopetisi 0,896. Dengan demikian, kuesioner penelitian dapat dinyatakan memenuhi syarat composite reliability karena memiliki nilai $>0.70$.

\section{Analisis Data}

Analisis jalur merupakan teknik menganalisis hubungan sebab akibat pada regresi berganda jika variabel independen mempengaruhi variabel dependen secara langsung dan tidak langsung yaitu melalui variabel mediator (Sarwono, 2011; Ghozali, 2013).Pada penelitian ini, analisis jalur dilakukan melalui PLS (Partial Least Square) dengan variabel mediator atau intervening. PLS digunakan untuk mencari komponen dari X yang terbaik untuk memprediksi Y (Ghozali, 2013). Pada penelitian ini, hubungan antara kompetisi dan kooperasi terhadap kinerja melalui koopetisi diambil dari kompetisi (X1) terhadap kinerja (Y), 
pengaruh kooperasi (X2) terhadap kinerja, dan pengaruh koopetisi (X3) terhadap kinerja.

\section{HASIL DAN PEMBAHASAN}

\section{Gambaran Umum Responden}

Berdasarkan hasil penelitian lapangan, responden penelitian ini adalah karyawan bagian penjualan atau kepala toko yang sedang bertugas jaga di toko. Responden dipilih karena kepala toko maupun karyawan bagian penjualan dinilai terlibat secara langsung dan memiliki pemahaman yang baik akan kondisi pasar yang sedang terjadi. Penelitian ini membutuhkan 1 responden setiap toko untuk menggambarkan kondisi pasar dan kondisi internal perusahaan. Dapat dilihat bahwa responden sebagian besar atau $71 \%$ merupakan karyawan bidang penjualan, sebanyak 16,1\% merupakan kepala toko, dan sebanyak 12,9\% memiliki jabatan lainnya seperti teknisi dan admin.

Berdasarkan data responden, sebagian besar atau 54,8\% dari keseluruhan sampel menjual produk utama laptop. Sebanyak 16\% toko menjual produk utama komputer, $16 \%$ toko menjual produk utama sparepart dan $13 \%$ toko menjual produk utama aksesoris komputer.

Berdasarkan data responden, sebagian besar atau 58\% toko berdiri pada tahun 2008-2016 yang berarti toko-toko ini merupakan golongan toko baru. Sebagian lainnya yaitu 22,6\% toko berdiri pada tahun 1999 - 2007, yang berarti 7 toko termasuk toko yang sudah cukup lama berjualan. Sebagian lain yaitu 9,7\% toko berdiri pada tahun 1990 - 1998, yang berarti 3 toko ini termasuk telah sangat lama mencapai 26 tahun berjualan di SCC atau Plasa Simpang Lima Semarang.

Berdasarkan data kelompok usaha responden, sebagian besar atau 41,9\% toko termasuk kelompok usaha kecil dengan omset 300 juta hingga 2,5 miliar rupiah per tahun. Sementara sebanyak 25,8\% toko termasuk kelompok usaha mikro dengan omset kurang dari 300 juta per tahun. Sebanyak 22,6\% toko 
JEMAP : Jurnal Ekonomi, Manajemen, Akuntansi dan Perpajakan

ISSN : 2622-612X (Media Online) | Vol. 2 | No. 1| April 2019

termasuk dalam kelompok usaha menengah dengan omset 2,5 miliar hingga 50 miliar per tahun.

\section{Tanggapan Responden}

\section{Penilaian Responden terhadap Kompetisi}

Pada penelitian ini, tanggapan responden terhadap variabel kompetisi sebagai berikut ini.

Tabel 2

Tanggapan Responden terhadap Item Kompetisi

\begin{tabular}{|c|c|c|c|c|c|c|c|c|}
\hline Item Kuesioner Kompetisi & $\begin{array}{c}1 \\
\text { STS }\end{array}$ & $\begin{array}{c}2 \\
\text { TS }\end{array}$ & $\begin{array}{l}\mathbf{3} \\
\mathbf{N}\end{array}$ & $\begin{array}{l}4 \\
\mathrm{~S}\end{array}$ & $\begin{array}{c}5 \\
\text { SS }\end{array}$ & total & $\begin{array}{l}\text { Rata- } \\
\text { rata } \\
\text { skor }\end{array}$ & Ket \\
\hline $\begin{array}{l}\text { Persyaratan mudah bagi toko } \\
\text { komputer baru untuk berjualan } \\
\text { di SCC }\end{array}$ & $\begin{array}{l}0 \\
(0)\end{array}$ & $\begin{array}{l}5 \\
(10)\end{array}$ & $\begin{array}{l}10 \\
(30)\end{array}$ & $\begin{array}{l}13 \\
(52)\end{array}$ & $\begin{array}{l}3 \\
(15)\end{array}$ & 107 & 3,45 & S \\
\hline $\begin{array}{l}\text { Toko yang telah dahulu ada di } \\
\text { SCC tidak mempersulit atau } \\
\text { menjatuhkan toko baru yang } \\
\text { berjualan di SCC. }\end{array}$ & $\begin{array}{l}1 \\
(1)\end{array}$ & $\begin{array}{l}3 \\
(6)\end{array}$ & $\begin{array}{l}8 \\
(24)\end{array}$ & $\begin{array}{l}15 \\
(60)\end{array}$ & $\begin{array}{l}4 \\
(20)\end{array}$ & 111 & 3,58 & $\mathrm{~S}$ \\
\hline $\begin{array}{l}\text { Konsumen sering } \\
\text { membandingkan harga antar } \\
\text { toko }\end{array}$ & $\begin{array}{l}0 \\
(0)\end{array}$ & $\begin{array}{l}0 \\
(0)\end{array}$ & $\begin{array}{l}3 \\
(9)\end{array}$ & $\begin{array}{l}14 \\
(56)\end{array}$ & $\begin{array}{l}14 \\
(70)\end{array}$ & 135 & 4,35 & SS \\
\hline $\begin{array}{l}\text { Konsumen mudah berpindah ke } \\
\text { toko lain apabila tidak terjadi } \\
\text { kesepakatan harga di toko saya. }\end{array}$ & $\begin{array}{l}0 \\
(0)\end{array}$ & $\begin{array}{l}1 \\
(2)\end{array}$ & $\begin{array}{l}6 \\
(18)\end{array}$ & $\begin{array}{l}13 \\
(52)\end{array}$ & $\begin{array}{l}11 \\
(55)\end{array}$ & 127 & 4,09 & S \\
\hline $\begin{array}{l}\text { Banyak toko menjual produk } \\
\text { sejenis }\end{array}$ & $\begin{array}{l}0 \\
(0)\end{array}$ & $\begin{array}{l}3 \\
(6)\end{array}$ & $\begin{array}{l}1 \\
(3)\end{array}$ & $\begin{array}{l}20 \\
(80)\end{array}$ & $\begin{array}{l}7 \\
(35) \\
\end{array}$ & 124 & 4 & S \\
\hline $\begin{array}{l}\text { Toko lain yang sejenis sering } \\
\text { memberi promosi yang menarik } \\
\text { konsumen saya }\end{array}$ & $\begin{array}{l}0 \\
(0)\end{array}$ & $\begin{array}{l}4 \\
(8)\end{array}$ & $\begin{array}{l}14 \\
(42)\end{array}$ & $\begin{array}{l}11 \\
(44)\end{array}$ & $\begin{array}{l}2 \\
(10)\end{array}$ & 104 & 3,35 & $\mathrm{~N}$ \\
\hline $\begin{array}{l}\text { Toko lain yang sejenis } \\
\text { menawarkan harga yang lebih } \\
\text { murah daripada toko saya }\end{array}$ & $\begin{array}{l}1 \\
(1)\end{array}$ & $\begin{array}{l}5 \\
(10)\end{array}$ & $\begin{array}{l}15 \\
(45)\end{array}$ & $\begin{array}{l}6 \\
(24)\end{array}$ & $\begin{array}{l}4 \\
(20)\end{array}$ & 100 & 3,23 & $\mathrm{~N}$ \\
\hline
\end{tabular}

Sumber: Data primer yang di olah, 2017

\section{Penilaian Responden terhadap Kooperasi}

Pada penelitian ini, variabel kooperasi merupakan variabel independen dengan tanggapan responden sebagai berikut. 
JEMAP : Jurnal Ekonomi, Manajemen, Akuntansi dan Perpajakan

Tabel 3

Tanggapan responden item Kooperasi

\begin{tabular}{|c|c|c|c|c|c|c|c|c|}
\hline Item Kuesioner Kooperasi & $\begin{array}{c}1 \\
\text { STS }\end{array}$ & $\begin{array}{c}2 \\
\text { TS }\end{array}$ & $\begin{array}{l}\mathbf{3} \\
\mathbf{N}\end{array}$ & $\begin{array}{l}4 \\
S\end{array}$ & $\begin{array}{c}5 \\
\text { SS }\end{array}$ & total & $\begin{array}{l}\text { Rata- } \\
\text { rata } \\
\text { skor }\end{array}$ & Ket \\
\hline $\begin{array}{l}\text { Saya ingin mengurangi } \\
\text { intensitas persaingan dengan } \\
\text { bekerjasama dengan toko lain } \\
\text { untuk mencapai kesejahteraan } \\
\text { bersama }\end{array}$ & $\begin{array}{l}2 \\
(2)\end{array}$ & $\begin{array}{l}2 \\
(4)\end{array}$ & $\begin{array}{l}10 \\
(30)\end{array}$ & $\begin{array}{l}15 \\
(60)\end{array}$ & $\begin{array}{l}2 \\
(10)\end{array}$ & 106 & 3,42 & S \\
\hline $\begin{array}{l}\text { Saya melakukan } \\
\text { informal (tidak terorganisasi) }\end{array}$ & $\begin{array}{l}0 \\
(0)\end{array}$ & $\begin{array}{l}7 \\
(14)\end{array}$ & $\begin{array}{l}12 \\
(36)\end{array}$ & $\begin{array}{l}12 \\
(48)\end{array}$ & $\begin{array}{l}0 \\
(0)\end{array}$ & 98 & 3,16 & $\mathrm{~N}$ \\
\hline $\begin{array}{ll}\text { Saya melakukan } & \text { kerjasama } \\
\text { formal } & \text { (kerjasama } \\
\text { terorganisasi) } & \end{array}$ & $\begin{array}{l}0 \\
(0)\end{array}$ & $\begin{array}{l}2 \\
(4)\end{array}$ & $\begin{array}{l}13 \\
(39)\end{array}$ & $\begin{array}{l}15 \\
(60)\end{array}$ & $\begin{array}{l}1 \\
(5)\end{array}$ & 108 & 3,48 & S \\
\hline $\begin{array}{l}\text { Saya berbagi sumber daya dan } \\
\text { informasi dengan sesama toko }\end{array}$ & $\begin{array}{l}0 \\
(0)\end{array}$ & $\begin{array}{l}6 \\
(12)\end{array}$ & $\begin{array}{l}9 \\
(27)\end{array}$ & $\begin{array}{l}14 \\
(56)\end{array}$ & $\begin{array}{l}2 \\
(10)\end{array}$ & 105 & 3,39 & $\mathrm{~N}$ \\
\hline $\begin{array}{l}\text { Saya membantu kesuksesan } \\
\text { toko lain melalui sumber daya } \\
\text { yang saya miliki }\end{array}$ & $\begin{array}{l}0 \\
(0)\end{array}$ & $\begin{array}{l}9 \\
(18)\end{array}$ & $\begin{array}{l}7 \\
(21)\end{array}$ & $\begin{array}{l}14 \\
(56)\end{array}$ & $\begin{array}{l}1 \\
(5)\end{array}$ & 100 & 3,23 & $\mathrm{~N}$ \\
\hline $\begin{array}{l}\text { Saya banyak mendapat bantuan } \\
\text { dari toko lain yang bekerjasama } \\
\text { dengan saya }\end{array}$ & $\begin{array}{l}0 \\
(0)\end{array}$ & $\begin{array}{l}6 \\
(12)\end{array}$ & $\begin{array}{l}10 \\
(30)\end{array}$ & $\begin{array}{l}11 \\
(44)\end{array}$ & $\begin{array}{l}4 \\
(20)\end{array}$ & 106 & 3,42 & $S$ \\
\hline $\begin{array}{l}\text { Melalui kerjasama antar toko, } \\
\text { saya dapat meningkatkan } \\
\text { efisiensi dan keuntungan } \\
\text { daripada mengandalkan sumber } \\
\text { daya saya sendiri }\end{array}$ & $\begin{array}{l}0 \\
(0)\end{array}$ & $\begin{array}{l}8 \\
(16)\end{array}$ & $\begin{array}{l}6 \\
(18)\end{array}$ & $\begin{array}{l}14 \\
(56)\end{array}$ & $\begin{array}{l}3 \\
(15)\end{array}$ & 105 & 3,39 & $\mathrm{~N}$ \\
\hline $\begin{array}{l}\text { Saya dan toko lain yang } \\
\text { bekerjasama sama-sama } \\
\text { mendapat keuntungan. }\end{array}$ & $\begin{array}{l}1 \\
(1)\end{array}$ & $\begin{array}{l}1 \\
(2)\end{array}$ & $\begin{array}{l}6 \\
(18)\end{array}$ & $\begin{array}{l}22 \\
(88)\end{array}$ & $\begin{array}{l}1 \\
(5)\end{array}$ & 114 & 3,68 & $\mathrm{~S}$ \\
\hline $\begin{array}{l}\text { Penting bagi saya untuk } \\
\text { mencapai tujuan bersama } \\
\text { daripada meraih keuntungan } \\
\text { sepihak saja. }\end{array}$ & $\begin{array}{l}1 \\
(1)\end{array}$ & $\begin{array}{l}2 \\
(4)\end{array}$ & $\begin{array}{l}13 \\
(39)\end{array}$ & $\begin{array}{l}13 \\
(52)\end{array}$ & $\begin{array}{l}2 \\
(10)\end{array}$ & 106 & 3,42 & S \\
\hline $\begin{array}{l}\text { Sumber daya dan informasi } \\
\text { yang kami dapat dari lain pihak } \\
\text { bermanfaat bagi kesuksesan } \\
\text { usaha kami bersama. }\end{array}$ & $\begin{array}{l}0 \\
(0)\end{array}$ & $\begin{array}{l}2 \\
(4)\end{array}$ & $\begin{array}{l}9 \\
(27)\end{array}$ & $\begin{array}{l}17 \\
(68)\end{array}$ & $\begin{array}{l}3 \\
(15)\end{array}$ & 114 & 3,68 & $S$ \\
\hline
\end{tabular}

Sumber: Data primer yang di olah, 2016

\section{Penilaian Responden terhadap Koopetisi}

Berikut ini tanggapan responden terhadap variabel koopetisi sebagai variabel mediator. 
JEMAP : Jurnal Ekonomi, Manajemen, Akuntansi dan Perpajakan

Tabel 4

Tanggapan responden item Koopetisi

\begin{tabular}{|c|c|c|c|c|c|c|c|c|}
\hline Item Kuesioner Koopetisi & $\begin{array}{c}1 \\
\text { STS }\end{array}$ & $\begin{array}{c}2 \\
\text { TS }\end{array}$ & $\begin{array}{l}\mathbf{3} \\
\mathbf{N}\end{array}$ & $\begin{array}{l}4 \\
S\end{array}$ & $\begin{array}{c}5 \\
\text { SS }\end{array}$ & total & $\begin{array}{l}\text { Rata- } \\
\text { rata } \\
\text { skor }\end{array}$ & Ket \\
\hline $\begin{array}{l}\text { Walaupun toko lain juga } \\
\text { adalah pesaing, saya tidak ragu } \\
\text { untuk membangun hubungan } \\
\text { kerjasama apabila hal tersebut } \\
\text { dapat memajukan bisnis saya. }\end{array}$ & $\begin{array}{l}0 \\
(0)\end{array}$ & $\begin{array}{l}1 \\
(2)\end{array}$ & $\begin{array}{l}6 \\
(18)\end{array}$ & $\begin{array}{l}24 \\
(96)\end{array}$ & $\begin{array}{l}0 \\
(0)\end{array}$ & 116 & 3,74 & $\mathrm{~S}$ \\
\hline $\begin{array}{l}\text { Walaupun partner saya adalah } \\
\text { pesaing saya, kami terbuka } \\
\text { untuk berbagi sumber daya dan } \\
\text { informasi. }\end{array}$ & $\begin{array}{l}0 \\
(0)\end{array}$ & $\begin{array}{l}4 \\
(8)\end{array}$ & $\begin{array}{l}7 \\
(21)\end{array}$ & $\begin{array}{l}20 \\
(80)\end{array}$ & $\begin{array}{l}0 \\
(0)\end{array}$ & 109 & 3,51 & S \\
\hline $\begin{array}{l}\text { Untuk membangun hubungan } \\
\text { kerjasama, kedua perusahaaan } \\
\text { harus memiliki tujuan yang } \\
\text { sama-sama menguntungkan. }\end{array}$ & $\begin{array}{l}0 \\
(0)\end{array}$ & $\begin{array}{l}2 \\
(4)\end{array}$ & $\begin{array}{l}6 \\
(18)\end{array}$ & $\begin{array}{l}22 \\
(88)\end{array}$ & $\begin{array}{l}1 \\
(5)\end{array}$ & 115 & 3,71 & S \\
\hline $\begin{array}{l}\text { Saya percaya toko yang } \\
\text { bekerjasama dengan saya jujur } \\
\text { pada saya dan dapat dipercaya } \\
\text { atau diandalkan }\end{array}$ & $\begin{array}{l}0 \\
(0)\end{array}$ & $\begin{array}{l}2 \\
(4)\end{array}$ & $\begin{array}{l}10 \\
(30)\end{array}$ & $\begin{array}{l}19 \\
(76)\end{array}$ & $\begin{array}{l}0 \\
(0)\end{array}$ & 110 & 3,55 & S \\
\hline $\begin{array}{l}\text { Hubungan akan terganggu } \\
\text { apabila partner saya mencoba } \\
\text { mengambil keuntungan dari } \\
\text { perusahaan saya secara } \\
\text { sepihak. }\end{array}$ & $\begin{array}{l}0 \\
(0)\end{array}$ & $\begin{array}{l}1 \\
(2)\end{array}$ & $\begin{array}{l}10 \\
(30)\end{array}$ & $\begin{array}{l}18 \\
(72)\end{array}$ & $\begin{array}{l}2 \\
(10)\end{array}$ & 114 & 3,67 & S \\
\hline $\begin{array}{l}\text { Sesama toko harus selalu jujur } \\
\text { dalam suatu hubungan }\end{array}$ & $\begin{array}{l}0 \\
(0)\end{array}$ & $\begin{array}{l}0 \\
(0)\end{array}$ & $\begin{array}{l}2 \\
(6)\end{array}$ & $\begin{array}{l}26 \\
(104)\end{array}$ & $\begin{array}{l}3 \\
(15)\end{array}$ & 125 & 4,03 & S \\
\hline $\begin{array}{l}\text { Saya berkomitmen untuk } \\
\text { menjaga hubungan baik dengan } \\
\text { toko lain yang bekerjasama } \\
\text { dengan saya. }\end{array}$ & $\begin{array}{l}0 \\
(0)\end{array}$ & $\begin{array}{l}1 \\
(2)\end{array}$ & $\begin{array}{l}5 \\
(15)\end{array}$ & $\begin{array}{l}19 \\
(76)\end{array}$ & $\begin{array}{l}6 \\
(30)\end{array}$ & 123 & 3,97 & S \\
\hline $\begin{array}{l}\text { kedua pihak toko harus } \\
\text { memiliki niat untuk membantu } \\
\text { memajukan usaha pihak } \\
\text { lainnya. }\end{array}$ & $\begin{array}{l}0 \\
(0)\end{array}$ & $\begin{array}{l}3 \\
(6)\end{array}$ & $\begin{array}{l}7 \\
(21)\end{array}$ & $\begin{array}{l}20 \\
(80)\end{array}$ & $\begin{array}{l}1 \\
(5)\end{array}$ & 112 & 3,61 & S \\
\hline $\begin{array}{l}\text { saya bersedia bertanggung } \\
\text { jawab dan berkomitmen untuk } \\
\text { tujuan bersama dari hubungan } \\
\text { kerjasama ini. }\end{array}$ & $\begin{array}{l}0 \\
(0)\end{array}$ & $\begin{array}{l}2 \\
(4)\end{array}$ & $\begin{array}{l}8 \\
(24)\end{array}$ & $\begin{array}{l}18 \\
(72)\end{array}$ & $\begin{array}{l}3 \\
(15)\end{array}$ & 115 & 3,71 & S \\
\hline
\end{tabular}

Sumber: Data primer yang di olah, 2016 


\section{Penilaian Responden terhadap Kinerja}

Pada penelitian ini, variabel kinerja merupakan variabel dependen yang akan menjadi tolok ukur pengaruh dari kompetisi; kooperasi; dan kompetisi dan kooperasi melalui koopetisi.

Tabel 5

Tanggapan responden terhadap Item Kinerja

\begin{tabular}{|l|l|l|l|l|l|l|l|l|}
\hline Item Kuesioner Kinerja & $\begin{array}{c}\mathbf{1} \\
\text { STS }\end{array}$ & $\begin{array}{c}\mathbf{2} \\
\text { TS }\end{array}$ & $\begin{array}{l}\mathbf{3} \\
\mathbf{N}\end{array}$ & $\begin{array}{l}\mathbf{4} \\
\mathbf{S}\end{array}$ & $\begin{array}{l}\mathbf{5} \\
\text { SS }\end{array}$ & total & $\begin{array}{l}\text { Rata- } \\
\text { rata } \\
\text { skor }\end{array}$ & Ket \\
\hline $\begin{array}{l}\text { Terjadi peningkatan jumlah unit } \\
\text { yang terjual }\end{array}$ & $\begin{array}{l}0 \\
(0)\end{array}$ & $\begin{array}{l}1 \\
(2)\end{array}$ & $\begin{array}{l}8 \\
(24)\end{array}$ & $\begin{array}{l}22 \\
(88)\end{array}$ & $\begin{array}{l}0 \\
(0)\end{array}$ & 114 & 3,68 & $\mathrm{~S}$ \\
\hline $\begin{array}{l}\text { Ada peningkatan jumlah } \\
\text { pengunjung toko }\end{array}$ & $\begin{array}{l}2 \\
(0)\end{array}$ & $\begin{array}{l}9 \\
(4)\end{array}$ & $\begin{array}{l}18 \\
(27)\end{array}$ & $\begin{array}{l}2 \\
(10)\end{array}$ & 113 & 3,65 & $\mathrm{~S}$ \\
\hline Adanya peningkatan laba & 0 & 1 & $\begin{array}{l}16 \\
(48)\end{array}$ & $\begin{array}{l}12 \\
(48)\end{array}$ & $\begin{array}{l}2 \\
(10)\end{array}$ & 108 & 3,48 & $\mathrm{~S}$ \\
\hline $\begin{array}{l}\text { Saya dapat mengurangi biaya } \\
\text { operasional }\end{array}$ & $\begin{array}{l}(2) \\
(0)\end{array}$ & $\begin{array}{l}5 \\
(10)\end{array}$ & $\begin{array}{l}12 \\
(36)\end{array}$ & $\begin{array}{l}13 \\
(52)\end{array}$ & $\begin{array}{l}1 \\
(5)\end{array}$ & 103 & 3,32 & $\mathrm{~N}$ \\
\hline $\begin{array}{l}\text { Adanya pertambahan jumlah } \\
\text { karyawan }\end{array}$ & $\begin{array}{l}8 \\
(0)\end{array}$ & $\begin{array}{l}15 \\
(16)\end{array}$ & $\begin{array}{l}8 \\
(45)\end{array}$ & $\begin{array}{l}0 \\
(32)\end{array}$ & 93 & 3,00 & $\mathrm{~N}$ \\
\hline $\begin{array}{l}\text { Kenaikan jumlah stok barang } \\
\text { ready stock }\end{array}$ & $\begin{array}{l}1 \\
(0)\end{array}$ & $\begin{array}{l}6 \\
(2)\end{array}$ & $\begin{array}{l}23 \\
(18)\end{array}$ & $\begin{array}{l}1 \\
(92)\end{array}$ & 117 & 3,77 & $\mathrm{~S}$ \\
\hline
\end{tabular}

Sumber: Data primer yang di olah, 2016

\section{Pengujian hipotesis}

Model penelitian diuji kelayakannya dengan melihat nilai R square. Output yang dihasilkan adalah sebagai berikut:

Tabel.6

Uji kelayakan model

\begin{tabular}{|l|l|}
\hline Variabel independen & Nilai R-square \\
\hline Kinerja & 0.427 \\
\hline Koopetisi & 0.268 \\
\hline
\end{tabular}

Sumber: Data primer yang diolah, 2016

Hasil R square menunjukkan bahwa sebanyak 42,7\% variabilitas konstruk kinerja dapat dijelaskan oleh konstruk kompetisi, kooperasi, dan koopetisi, sedangkan sebanyak 57,3\% dijelaskan oleh variabel lain di luar yang diteliti. Sebanyak 26,8\% variabilitas konstruk koopetisi dapat dijelaskan oleh variabel kompetisi dan kooperasi, sedangkan sisanya dijelaskan oleh variabel lain di luar yang diteliti. Pengujian hipotesis pada penelitian ini menggunakan metode bootstrapping pada 
program statistik SmartPLS. Penerimaan atau penolakan hipotesis melihat dari signifikansi pengaruh melalui besarnya nilai koefisien parameter dan nilai signifikansi t statistik.

Tabel 7.

Uji t statistik

\begin{tabular}{|l|l|l|}
\hline \multicolumn{1}{|c|}{ Model } & Original Sample & T statistic \\
\hline Kompetisi $\rightarrow$ Kinerja & $-0,025$ & 0.181 \\
\hline Kompetisi $\rightarrow$ Koopetisi & 0,251 & 1.399 \\
\hline Kooperasi $\rightarrow$ Kinerja & 0,602 & 3.190 \\
\hline Kooperasi $\rightarrow$ Koopetisi & 0,374 & 2.007 \\
\hline Koopetisi $\rightarrow$ Kinerja & 0,114 & 0.618 \\
\hline
\end{tabular}

Sumber: Data Primer yang diolah, 2016

\section{Pengaruh kompetisi dan kooperasi melalui koopetisi terhadap kinerja perusahaan}

Pengujian hipotesis keenam sebagai berikut:Ho6: Kompetisi dan kooperasi melalui koopetisi tidak berpengaruh terhadap kinerja perusahaan.Hipotesis diuji melalui bootstrapping SmartPLS dengan kriteria Ho6 ditolak apabila t hitung lebih besar daripada t tabel (2,042).

Tabel 8

Hasil pengujian hipotesis indirect effect

\begin{tabular}{|c|c|c|}
\hline Jalur & Original Sample & T statistic \\
\hline Kompetisi $\rightarrow$ kinerja & 0.029 & 0.729 \\
\hline Kooperasi $\rightarrow$ kinerja & 0.043 & 0.698 \\
\hline
\end{tabular}

Sumber: Data primer yang diolah, 2016

Berdasarkan hasil uji tersebut didapati hasil output nilai t hitungdari kompetisi melalui koopetisi terhadap kinerja adalah sebesar 0.729, dan kooperasi melalui koopetisi terhadap kinerja adalah sebesar 0,698 sedangkan nilai t tabel pada signifikansi 5\% = 2,042. Maka dapat disimpulkan t hitung $<\mathrm{t}$ tabel pada tingkat kepercayaan 95\%. Berdasarkan hasil tersebut, hipotesis Ho6diterima yang berarti kompetisi dan kooperasi melalui koopetisi tidak berpengaruh terhadap kinerja perusahaan. 
Berkooperasi dan berkompetisi melalui koopetisi tidak menggambarkan pengaruhnya terhadap kinerja. Dalam teori koopetisi menurut Luo (2004) dan Aladag (2003), koopetisi adalah fenomena simultan antara kompetisi dan kooperasi dalam satu hubungan untuk meraih manfaat dari sinergi dan efisiensi bagi bisnisnya. Namun pada SCC, kompetisi yang terjadi tidak mempengaruhi koopetisi, yang berarti kompetisi yang dilakukan masing-masing toko bukan dilakukan dalam SCC. Sehingga kompetisi yang terjadi tidak dapat mempengaruhi kinerja.

Kooperasi yang terjadi di SCC terjadi antar toko di SCC, namun hasil penelitian koopetisi tidak mempengaruhi kinerja. Dengan demikian, hasil uji menunjukkan tidak ada pengaruh tidak langsung dari kooperasi melalui koopetisi terhadap kinerja. Ketidakseimbangan manfaat kompetisi dan kooperasi ini tidak dapat membentuk koopetisi. Selain itu, pengujian pengaruh koopetisi secara independen tidak mempengaruhi kinerja perusahaan. Dengan demikian koopetisi juga tidak dapat berperan signifikan dalam mediasi kompetisi dan kooperasi untuk meningkatkan kinerja perusahaan.

\section{Tabel 9}

Hipotesis, Signifikansi, dan Hasil Uji Hipotesis

\begin{tabular}{|l|l|l|l|}
\hline No & Hipotesis & Signifikansi & Hasil \\
\hline 1 & $\begin{array}{l}\text { Kompetisi tidak berpengaruh } \\
\text { terhadap kinerja }\end{array}$ & $\begin{array}{l}0,181<\mathrm{t} \text { tabel } \\
\text { (non-signifikan) }\end{array}$ & Ho1Diterima \\
\hline 2 & $\begin{array}{l}\text { Kooperasi tidak berpengaruh } \\
\text { terhadap kinerja }\end{array}$ & $\begin{array}{l}3,190>\mathrm{t} \text { tabel } \\
(\text { signifikan) }\end{array}$ & Ho2Ditolak \\
\hline 3 & $\begin{array}{l}\text { Kompetisi tidak berpengaruh } \\
\text { terhadap koopetisi }\end{array}$ & $\begin{array}{l}1,399<\mathrm{t} \text { tabel } \\
(\text { non-signifikan) }\end{array}$ & Ho3Diterima \\
\hline 4 & $\begin{array}{l}\text { Kooperasi tidak berpengaruh } \\
\text { terhadap koopetisi }\end{array}$ & $\begin{array}{l}2,077>\mathrm{t} \text { tabel } \\
(\text { signifikan) }\end{array}$ & Ho4Ditolak \\
\hline 5 & $\begin{array}{l}\text { Koopetisi tidak berpengaruh } \\
\text { terhadap kinerja }\end{array}$ & $\begin{array}{l}0,618<\mathrm{t} \text { tabel } \\
\text { (non-signifikan) }\end{array}$ & Ho5Diterima \\
\hline 6 & $\begin{array}{l}\text { Kompetisi dan kooperasi melalui } \\
\text { koopetisi tidak berpengaruh } \\
\text { terhadap kinerja }\end{array}$ & $\begin{array}{l}\text { 0,729 }<\mathrm{t} \text { tabel } \\
0,698<\mathrm{t} \text { tabel } \\
\text { (non-signifikan) }\end{array}$ & Ho6Diterima \\
\hline
\end{tabular}

Sumber: Data primer yang diolah, 2016 


\section{Implikasi Manajerial}

Berdasarkan hasil penelitian yang telah dilakukan, kooperasi berpengaruh terhadap kinerja perusahaan. Hal ini berarti semakin tinggi intensitas kooperasi semakin meningkatkan kinerja perusahaan. Berkooperasi dapat membantu perusahaan untuk berbagi sumber daya dan informasi. Manajer perlu mempertahankan bahkan meningkatkan kerjasama yang terjalin antar toko melalui penyediaan produk yang dibutuhkan toko lain, dukungan konsinyasi, melakukan kerjasama informal seperti melakukan kesepakatan harga jual, bergabung dalam asosiasi pedagang dan berbagi informasi antar penjual.

Kompetisi yang terjadi antar toko tidak berpengaruh terhadap koopetisi. Dalam jangka panjang apabila hal ini tidak ditanggapi manajer, dapat mengurangi ketertarikan konsumen untuk membeli di SCC karena banyak event pameran komputer di tempat lain yang dapat memberikan promosi dan kompetisi harga yang menarik daripada di SCC. Untuk itu, manajemen SCC perlu menumbuhkan kompetisi dalam hal efisiensi antar toko atau kompetisi dalam hal kecepatan dan kualitas layanan ke konsumen. Manajer SCC juga dapat mengadakan appreciation night yang merupakan ajang reward bagi toko dengan penjualan terbaik, layanan terbaik, dan lain-lain.

Kooperasi dengan berbagi sumber daya dan informasi juga dapat menimbulkan ide-ide inovatif dari masing-masing toko mengenai program untuk meningkatkan daya tarik SCC bagi konsumen, menarik konsumen untuk membeli komputer dan gadget hanya di SCC, memperbaiki dan meningkatkan kenyamanan konsumen SCC dan inovasi lainnya.Toko-toko dapat bekerjasama secara serentak memberikan diskon akhir tahun di SCC, atau bekerjasama memberikan undian grand prize bagi konsumen atas pembelian di toko manapun dalam area SCC dengan mengundi nota pembelian. SCC juga dapat mengundang suatu sekolah untuk workshop komputer atau gadget di fasilitas training center yang tersedia di SCC, dan cara inovatif lainnya untuk menarik konsumen ke SCC. 
Hasil penelitian ini menyatakan bahwa koopetisi tidak berpengaruh terhadap kinerja perusahaan.Hal ini berarti koopetisi yang terjadi dalam SCC tidak meningkatkan kinerja perusahaan. Berkumpulnya toko-toko dalam satu area SCC tidak menunjukkan adanya koopetisi, melainkan pemilik toko hanya sekedar membuka toko di SCC sebagai tempat berjualan, tanpa berniat untuk berkompetisi di SCC untuk berebut mendapatkan business pie yang terbesar. Dengan demikian, toko-toko dapat menerapkan alternatif bentuk koopetisi di luar SCC untuk meningkatkan kinerja mereka seperti dengan bekerjasama sepakat mengikuti pameran komputer dan gadget yang sama. Dengan mengikuti suatu pameran komputer yang sama mereka dapat berkoopetisi untuk meningkatkan kinerja walaupun tidak dalam area SCC.

Di SCC kompetisi dan kooperasi melalui koopetisi juga tidak mempengaruhi kinerja perusahaan. Hal ini dapat disebabkan karena SCC menjadi tempat berkumpulnya toko-toko namun kurang menunjukkan SCC sebagai pasar yang menarik konsumen. Dengan demikian, dari segi pengelola SCC maupun kerjasama antar toko di SCC perlu mengadakan suatu event yang menarik baik konsumen untuk datang maupun penjual untuk lebih bergairah dalam berkompetisi dan bekerjasama antar toko di SCC. Pengelola perlu mengadakan workshop gratis bagi manajer dan sales toko tentang strategi pemasaran yang cocok di SCC dan pengelolaan UMKM, mengadakan event promosi tertentu yang mengundang masyarakat mengunjungi SCC.

Tabel 10

Sintesa hasil pengujian hipotesis dan implikasi manajerial

\begin{tabular}{|l|l|}
\hline \multicolumn{1}{|c|}{ Hasil pengujian hipotesis } & \multicolumn{1}{c|}{ Implikasi Manajerial } \\
\hline $\begin{array}{l}\text { Kompetisi tidak berpengaruh } \\
\text { terhadap kinerja }\end{array}$ & $\begin{array}{l}\text { Mencari bentuk-bentuk persaingan baik harga } \\
\text { maupun non harga. }\end{array}$ \\
\hline $\begin{array}{l}\text { Kooperasi berpengaruh } \\
\text { terhadap kinerja }\end{array}$ & $\begin{array}{l}\text { Meningkatkan dan mempertahankan berbagai } \\
\text { macam kooperasiyang dilakukan antar penjual. }\end{array}$ \\
\hline $\begin{array}{l}\text { Kompetisi tidak berpengaruh } \\
\text { terhadap koopetisi }\end{array}$ & $\begin{array}{l}\text { Manajemen SCC perlu menumbuhkan } \\
\text { kompetisi efisiensi antar toko atau kompetisi } \\
\text { kecepatan dan kualitas layanan ke konsumen } \\
\text { sehingga walaupun di tempat yang sama }\end{array}$ \\
\hline
\end{tabular}


JEMAP : Jurnal Ekonomi, Manajemen, Akuntansi dan Perpajakan ISSN : 2622-612X (Media Online) | Vol. 2 | No. 1| April 2019

\begin{tabular}{|l|l|}
\hline \multicolumn{1}{|c|}{ Hasil pengujian hipotesis } & \multicolumn{1}{c|}{ Implikasi Manajerial } \\
\hline $\begin{array}{l}\text { Kooperasi berpengaruh } \\
\text { terhadap koopetisi }\end{array}$ & $\begin{array}{l}\text { Bekerjasama mempertahankan dan } \\
\text { meningkatkan pangsa pasar di SCC melalui } \\
\text { strategi promosi serentak antar toko di SCC. }\end{array}$ \\
\hline $\begin{array}{l}\text { Koopetisi tidak berpengaruh } \\
\text { terhadap kinerja }\end{array}$ & $\begin{array}{l}\text { Melakukan strategi secara seimbang baik } \\
\text { kompetisi maupun kooperasi untuk } \\
\text { meningkatkan kinerja dengan promosi atau } \\
\text { penjualan bersama di luar SCC. }\end{array}$ \\
\hline $\begin{array}{l}\text { Kompetisi dan kooperasi } \\
\text { melalui koopetisi tidak } \\
\text { berpengaruh terhadap kinerja }\end{array}$ & $\begin{array}{l}\text { Memperjelas adanya koopetisi dengan } \\
\text { meningkatkantraffic pengunjung/konsumen } \\
\text { dan meningkatkan jumlah pemain dalam SCC. }\end{array}$ \\
\hline
\end{tabular}

\section{KESIMPULAN DAN SARAN}

Berdasarkan hasil penelitian pengaruh variabel kompetisi, kooperasi, dan koopetisi terhadap kinerja perusahaan di SCC Plasa Simpang Lima Semarang, maka peneliti menyimpulkan hasil temuan sebagai berikut: koopetisi tidak berpengaruh terhadap kinerja perusahaan. Kooperasi berpengaruh positif signifikan terhadap kinerja perusahaan. Kompetisi tidak berpengaruh terhadap koopetisi. Kooperasi berpengaruh positif signifikan terhadap koopetisi. Koopetisi tidak berpengaruh terhadap kinerja.

Kompetisi dan kooperasi secara tidak langsung melalui koopetisi tidak berpengaruh terhadap kinerja perusahaan. Hal ini menunjukkan adanya koopetisi sebagai variabel intervening dalam jalur kompetisi terhadap kinerja dan jalur kooperasi terhadap kinerja tidak dapat menggambarkan pengaruh secara tidak langsung terhadap kinerja sebagaimana yang dimaksudkan dalam model.

Berdasarkan hasil penelitian yang telah dilakukan, maka saran yang dapat diberikan untuk toko-toko yang berjualan di SCC adalah sebagai berikut:Toko di SCC perlu mencoba menerapkan strategi persaingan dalam hal harga dan juga non-harga. Misalnya seperti diferensiasi produk, diferensiasi pelayanan, layanan online shopping, dan lain-lain.Mengadakan event promosi yang diikuti toko-toko di SCC secara bersama-sama seperti hadiah bagi konsumen yang membeli produk 
di toko manapun di SCC, diskon khusus atau voucher belanja di toko manapun di SCC.Mempertahankan dan meningkatkan kerjasama antar toko. Meningkatkan kompetisi efisiensi dan kompetisi pelayanan sebagai keunggulan bersaing masingmasing toko sebagai ciri khas atau pembeda dari toko lain.Memberikan promo harga sewa kios bagi toko komputer baru.Memperbaharui tata ruang dan kenyamanan di SCC.

\section{DAFTAR PUSTAKA}

Aladag, Duygu. 2013.Network Coopetition: An Empirical Analysis with Multiple Case Approach. University of Edinburgh: Dissertation in International Business and Emerging Markets

Bengtsson, Maria and Soren Kock. 2000. “Coopetition” in Business Networks to Cooperate and Compete Simultaneously.EIsevier Science: Industrial Marketing Management, 29 : 411 -426

Dana, Leo Paul, Julian Granata, Frank Lasch, dan Alan Carnaby. 2013. The 'evolution of Coopetition in the Waipara Wine Cluster of New Zealand. Wine Economics and Policy, 2 : 42-29

Eikobrokk, Tom R. dan Dag H. Olsen. 2005. Coopetition and e-business success in SMEs: An Empirical Investigation of European SMEs. The 38th Hawaii International Conference on System Sciences.

Evans, Vaughan. 2013. Key Strategic Tools. UK : Pearson Education

Garcia, Cristina Quintana., Carlos A Benavides Velasco. 2002. Coopetition and Performance: Evidence from European Biotechnology Industry. Annual Conference of EURAM “Innovate Research in Management”, Swedia : 911 Mei 2002.

Ghozali, Imam. 2013. Aplikasi Analisis Multivariate dengan Program IBM SPSS 21. Semarang: Badan Penerbit Universitas Diponegoro. 
Ghozali, Imam. 2014. Structural Equation Modeling: Metode alternatif dengan Partial Least Square (PLS). Semarang: Badan Penerbit Universitas Diponegoro.

Granata, Julien. 2013. The Multiplication of Coopetitive Strategies in South of France Wine Industry. 7th AWBR International Conference, 12-15 Juni 2013.

Hoetoro, Arif. 2014. Cooperation and Competition among Clustered MSEs in East Java. Gadjah Mada International Journal of Business, Vol. 16 (3): halaman 275-293.

Hooley, Graham., Nigel Piercy, Brigitte Nicoulaud. 2008. Marketing Strategy and Competitive Positioning. Inggris: Pearson Education

Johansson, Marlene. 2012. The Balancing Act - Cooperating with Competitors. Swedia : Umea School of Business and Economics.

Kasali, Rhenald. 2006. Koopetisi (Bagian 1).http://pekalongankab.go.id/fasilitasweb/artikel/ekonomi/135-koopetisi.htmlDiunduh tanggal 15 September 2015.

Kossyva, Dorothea dan Katerina Sarri dan Nikolaos Georgopoulos. 2014. Coopetition: A Business Strategy for SMEs in Times of Economic Crisis. 2014. South-Eastern Europe Journal of Economics, 1: 89-106

Lendel, Viliam. 2007. The Value Net. Journal of Information, Control and Management Systems, Vol. 5 No.2 : 241-249

Li, Jiahong. 2015. The Benefit and Drawbacks of Coopetition on Performance of SMEs. 5th IBA Bachelor Thesis Conference University of Twente, Belanda: 2 Juli 2015.

Morris, Michael H., Akin Kocak, dan Alper Ozer. 2007. Coopetition as a Small Business Strategy: Implications for Performance. Journal of Small Business Strategy, Volume 18 (1): 35. 
Porter, Michael E.1998. Competitive Strategy: techniques for analyzing industries and competitors: with a new introduction. New York: The Free Press

Prasastyo, Klemens Wedanaji. 2010. Coopetition-Strategi Memenangkan Persaingan melalui Value Creation. Media Bisnis, September 2010.

Reynolds, Anne. 2013. Defining The Value of The Cooperative Business Model: An Introduction. CHS Center for Cooperatives Growth.

Ritala, Paavo; Arash Golnamm; dan Alain Wegmann. 2014. Coopetition-based business models: The Case of Amazon.com. Industrial Marketing Management Journal. Vol 43 (2): 236-249.

Roy, Frederic Le dan Famara Hyacinthe Sanou. 2014. Does Coopetition Strategy Improve Market Performance? An Empirical Study in Mobile Phone Industry. Journal of Economics and Management, Vol 17: 63 - 94.

Sarwono, Jonathan. 2011. Mengenal Path Analysis: Sejarah, Pengertian dan Aplikasi. Jurnal IImiah Manajemen Bisnis, Vol. 11 (2): 285-296.

Siregar, Suzanna L. 2006. Koopetisi Industri Perbankan di Indonesia. Prosiding Seminar Nasional Manajemen Teknologi IV, Surabaya 5 Agustus 2006.

Utomo, Tri Joko. 2010. Lingkungan Bisnis dan Persaingan Bisnis Ritel. Fokus Ekonomi, Vol 5 (1) : 70-80.

Walley, Keith. 2007. Coopetition: An Introduction to the Subject and an Agenda for Research. International Studies of Management and Organization, Vol. 37 (2) : 11-31.

Waxse, David J,. 2012. Cooperation-What Is It and Why Do It?. Richmond Journal of Law \& Technology, Vol.18 (3).

Widarjono, Agus. 2010. Analisis Multivariat Terapan dengan Program SPSS, AMOS, dan SMARTPLS.Yogyakarta : UPP STIM YKPN. 